Information for citation:

Matveev A. G. Krug smezhnykh prav v mezhdunarodnom prave i natsional'nykh pravovykh sistemakh [Neighboring Rights in International Law and National Legal Systems]. Vestnik Permskogo Universiteta. Juridicheskie Nauki - Perm University Herald. Juridical Sciences. 2017. Issue 38. Pp. 484-496. (In Russ.). DOI: 10.17072/1995-41902017-38-484-496.

UDC 347.78

DOI: 10.17072/1995-4190-2017-38-484-496

\title{
NEIGHBORING RIGHTS IN INTERNATIONAL LAW AND NATIONAL LEGAL SYSTEMS
}

\section{A. G. Matveev}

Perm State University, 15, Bukireva st., Perm, 614990, Russia

ORCID: 0000-0002-5808-939X

ResearcherID: F-1946-2016

Articles in DB "Scopus" / "Web of Science":

DOI: $10.17072 / 1995-4190-2016-33-348-353$

e-mail: la-musica@yandex.ru

Introduction: audio recording, radio and other inventions made it possible to exploit creative works in new ways. Consequently, there arose new issues concerning protection of property interests of performers, phonogram producers, TV and radio broadcasting organizations. All the disputes over this problem had one common theme - the theme of copyright. This very connection with copyright law gave the name for the emerging institute - neighboring or related rights. Purpose: to determine the range of neighboring rights in international law, legal systems of foreign countries and Russia, to systematize national approaches to regulation of neighboring rights. Methods: methods of formal logic, historical, comparative law, systemstructural and formal dogmatic methods are used in the analysis. Results: despite international standards for the regulation of neighboring rights, legal protection of these rights in foreign countries is characterized by a significant diversity. The first group of national legal systems includes those countries which do not protect related rights. In countries of the second group, neighboring rights are not recognized as such, while the relevant interests are protected by copyright law and legal institutes which are external towards it. The third group mainly includes countries with Anglo-American law, where some objects come under copyright law, while others are covered by rights which are recognized within copyright law but at the same time institutionally separated from copyrights. The fourth group comprises the states with the Civil law system. Here all the classical neighboring rights are institutionally separated from copyrights. Conclusions: Russia has established protection of neighboring rights under the influence of international and European law, and not national legal traditions. This refers to the rights specified in Chapter 71 of the Civil Code. However, Russian law directly or indirectly also recognizes other rights which are neighboring rights by their nature.

Keywords: neighboring rights; related rights; copyright; rights of performers; rights of phonogram producers; rights of broadcasting organizations; right of museums to publish museum items; publisher right; right of an audiovisual work producer; other rights

(C) Matveev A. G., 2017 


\title{
Information in Russian
}

\section{КРУГ СМЕЖНЫХ ПРАВ В МЕЖДУНАРОДНОМ ПРАВЕ И НАЦИОНАЛЬНЫХ ПРАВОВЫХ СИСТЕМАХ}

\author{
А. Г. Матвеев \\ 614990, Россия, г. Пермь, ул. Букирева, 15 \\ ORCID: 0000-0002-5808-939X \\ ResearcherID: F-1946-2016 \\ Статьи в БД «Scopus» / «Web of Science»: \\ DOI: $10.17072 / 1995-4190-2016-33-348-353$ \\ e-mail: la-musica@yandex.ru
}

Доктор юридических наук, доцент, профессор кафедры гражданского права Пермский государственный национальный исследовательский университет

Введение: звукозапись, радио и другие изобретения позволили использовать произведения новыми способами. Соответственно, они стали катализатором проблемь зашиты имущественных интересов артистов-исполнителей, производителей фонограмм, организаичий теле- и радиовещчания. Все обсуждения данной проблемы объединяла одна общая тема тема авторского права. Именно связь с авторским правом и позволила дать название зарождающемуся институту - «смежные права». Цель: определить круг смежных прав в международном праве, правовых системах зарубежных стран и Российской Федерации, систематизировать нацииоальные подходы к регламентации смежных прав. Методы: в исследовании применены методы формальной логики, исторический, сравнительно-правовой, системно-структурный и формально-догматический методыл. Результаты: несмотря на международные стандарты охраны смежных прав, национальная регламентация последних характеризуется существенным разнообразием. Первую группу национальных правовых систем образуют те, в которых вообще не охраняются смежные права. Вторая группа характеризуется тем, что здесь смежные права как таковые не признаются, а соответствующчие интересы охраняются авторским правом и внешними по отношению к нему правовыми институтами. В третью группу включаются преимущественно государства англоамериканского права, где в отношении одних объектов действуют авторские права, а в отношении других - права, которые признаются в рамках законов об авторском праве, но в то же время эти права институционально обособляются от авторских прав. В четвертую группу следует отнести государства континентального права. Здесь все классические смежные права институционально обособляются от авторского права. Выводы: Россия установила охрану смежных прав под влиянием международного и европейского права, а не национальных юридических традиций. Речь идет о правах, которые указаны в главе 71 Гражданского кодекса. Однако российское законодательство прямо или косвенно признает также другие права, которые по своей природе являются смежными правами.

Ключевые слова: смежные права; авторское право; права исполнителей; права производителей фонограмм; права вещательных организаций; право музеев на публикацию музейных предметов; право издателя; право изготовителя аудиовизуального произведения; другие права

\section{Introduction}

The world history of intellectual property law (intellectual law) dates back about three centuries. Three classical institutes - copyright law, patent law, means of individualization law - have been established in intellectual property law within this period of time, being quite short in the context of civil law development. These institutes could be called "three pillars of intellectual law". Last century was characterized by a significant expansion of intellectual property law over a number of objects. The most critical factor for this dynamics was an extensive technological breakthrough. The turn of the $19^{\text {th }}$ and $20^{\text {th }}$ centuries saw such inventions as audio record- ing, radio, cinema, television, which later were widely spread across the world. A new approach was applied to the way works of other people were exploited. These inventions appeared to be accelerating agents for the protection of the property interests of artists-performers, audio record producers, organizers of TV and radio broadcasting.

Originally, lawyers did not have any consensus on the legal mechanisms which should be applied to protect artists' performances, recorded audio tracks and broadcasted TV programs. However, disputes over this issue had one common theme - the theme of copyright as exploitation of all the above mentioned objects was somehow 
connected with works protected under copyright law. This very connection with copyright law gave the name for the emerging institute - "neighboring rights" or "related rights".

Internationally, the term "neighboring rights" was originally used in the Recommendations of 1948 Brussels Conference, which initiated revision of the Bern Convention for the Protection of Literary and Artistic Works (9 September, 1886) ${ }^{1}$. Article 8 of the Recommendations states that since interpretations of performers are artistic by their nature, the Convention wishes the studies of the rights related to copyright, including performers' rights, to be continued [5].

As for the national laws, Austrian Law on Copyright in Works of Literature and Art and on Related Rights of 9 April, $1936^{2}$ was the first to recognize neighboring rights. It is important to note that the term "verwandte Schutzrechte" (related rights) was used both in the title and in the wording of the Law since its approval ${ }^{3}$. Interestingly, D. Liptsik's work, which is quite popular among Russian scientists, states that the term "neighboring rights", meaning the protection of performers' rights, was originally used in Italian Law on Copyright and Neighboring Rights Protection of 22 April, 1941 [2, p. 303]. The second part of this Law had a title "Disposizioni sui diritti connessi all'esercizio del diritto d'autore" (Regulations about the rights related to copyright law) ${ }^{4}$. From the very beginning, the Laws in Austria and Italy provided for protection of neighboring rights to such objects as performances, audio recordings, photos, por-

\footnotetext{
${ }^{1}$ Berne Convention for the Protection of Literary and Artistic Works of September 9, 1886. Available at: http://www.wipo. int/treaties/en/text.jsp?file_id=283698 (accessed 01.07.2017).

${ }^{2}$ Federal Law on Copyright in Works of Literature and Art and on Related Rights of the Austria of April 9, 1936. Available at: https://www.ris.bka.gv.at/GeltendeFassung.wxe?Abfrage=Bundes normen\&Gesetzesnummer $=10001848$ (accessed 01.07.2017).

${ }^{3}$ Bundesgesetz über das Urheberrecht an Werken der Literatur und der Kunst und über verwandte Schutzrechte (Urheberrechtsgesetz) vom 09.04.1936. Available at: http://alex.onb.ac. at/cgi-content/alex?apm $=0 \&$ aid $=$ bgl\&datum $=19360004 \&$ seite $=00000131 \&$ size $=45$ (дата обращения: 08.08.2017); см. также французский текст этого Закона в ред. 1936 г. URL: http://www.wipo.int/wipolex/en/text.jsp?file_id=124736 (accessed 01.07.2017).

${ }^{4}$ Law for the Protection of Copyright and Neighboring Rights of the Italy of April 22, 1941. Available at: http://www.wipo. int/wipolex/en/details.jsp?id=2582 (accessed 01.07.2017).
}

traits, letters and diaries, names of works. Italian Law also established protection for radio programs, sketches of theatrical decorations, engineering drawings, exterior look of publications.

We are certain to say that the term "neighboring rights" was initially used in legal documents as a draft and temporary name for the emerging institute. However, later this phrase became widely spread and valid. D. Liptsik is quite right to say that the phrase "neighboring rights" has no theoretical background, and its meaning is not defined [2, p. 305]. Indeed, the main idea or function of the corresponding institutes is more vividly expressed in such words as "copyright law", "patent law", "means of individualization law" in comparison with the term "neighboring rights". Lack of an appropriately expressed message in the wording "neighboring rights" resulted in the situation (or at least contributed to it) when lists of these rights significantly differ in legislations of different countries. Along with that, artists' rights to their performances appear to be the common ground for these lists.

Neighboring rights tend to be absolute property rights for particular immaterial objects, that is, exclusive rights. It means that establishment of these rights limits public interests in free exploitation of the corresponding objects. Presently, the institute of neighboring rights is likely to be the most dynamically developed institute in the area of intellectual property law, in the sense that here exclusive rights expand over the public interests the most. However, these processes are remarkably combined with insufficient scientific research in the problems of justification, idea and range of neighboring rights. The majority of research works concerning neighboring rights deal with separate objects of this institute and laws around them. The last fifteen years in Russia have seen about ten $\mathrm{PhD}$ dissertations devoted to particular aspects of the neighboring rights. Along with that, no fundamental work providing the justification and the solution for the system of neighboring rights has been published so far.

This paper should partly fill the gaps in the area of fundamental scientific research on the neighboring rights system. 


\section{The Circle of Neighboring Rights in International Law}

As compared to the development of copyright law, international agreements played a critical role in the process of national recognition of neighboring rights. The main characteristics of copyright law in the leading European countries were vividly expressed at the turn of the $19^{\text {th }}-20^{\text {th }}$ centuries, when the countries signed and extensively developed the Berne Convention for the Protection of Literary and Artistic Works. The author of the present paper again points out the idea that the Berne Convention is a compromise between different traditions of copyright law. It is successful in giving the solution to construction of an international multilateral agreement which provides high degree of copyright protection. In contrast, international protection of neighboring rights started its development earlier than these rights were recognized in the majority of these countries. Besides, conventions in the area of intellectual property are known for their norms to be pioneering, innovative in respect to national legislations.

The Berne Union was the starting point to discuss the international recognition of the rights of artists-performers and producers of audio recordings. When revising the Berne Convention in Rome (1928), a project was proposed to include, for example, an article with the provisions establishing exclusive rights of artists-performers to distribution of their performances. This proposal was rejected at the Conference since provisions concerning protection for performers should not be included into the Convention devoted to copyright law.

The Brussels Conference (1948) returned to the issue of protecting the rights of performers, phonograms producers, as well as organizers of broadcasting, within the Berne Convention. And again the proposal to include the provisions concerning protection of the respective rights was rejected. S. Ricketson cites an interesting opinion explaining the main reason for rejecting further measures to recognize these rights within the Convention - there was a decision to avoid the pointless disagreement gap between the members of the Berne Union, many of whom hold opposite opinions [9, p. 1210]. Regarding further work on protection of the rights of performers, phonogram producers and broadcasting organizations, the participants of the Brussels Conference worked out only three recommendations, with one of them being devoted to artists' rights, which has already been mentioned above.

In 1951 experts of the joint committee organized by the International Bureau of the Berne Union started to design a project for international convention on the protection of interests of performers, producers of phonograms and broadcasting organizations. This process took about a decade. The representatives from UNESCO and International Labor Organization were involved into the discussion as well. Subsequently, in 1961 Rome hosted a diplomatic conference which was the platform to sign the International Convention for the Protection of Performers, Producers of Phonograms and Broadcasting Organizations ${ }^{1}$.

The phrase "neighboring rights" is used neither in the title, nor in the text of the Rome Convention. However, this very document gives modern understanding of conventional neighboring rights. It is clearly shown in the title of the Convention and backed up by its provisions that the objects to be protected are performances, phonograms and broadcasted programs. The rights of producers of phonograms (Article 10) and broadcasting organizations (Article 13) follow the model of exclusive rights, in other words, the mentioned articles use the expression "the right to authorize or to prohibit". Interestingly, Article 7 of the Convention characterizes performers' rights with a phrase "possibility of preventing". This expression, which is clearly not so limiting, was exploited in the Convention to allow Great Britain to protect performers' rights on the grounds of criminal law.

The Convention for the Protection of Producers of Phonograms Against Unauthorized Duplication of Their Phonograms of 29 October, 1971, adopted in Geneva, was the next international agreement in the area of neighboring rights ${ }^{2}$. The purpose of the Convention was to promote the protection of interests of phonogram producers against unauthorized duplication of phonograms and against import of these duplicates into any stateparticipant. At the same time, the Convention does not use the term "neighboring rights" and does not

\footnotetext{
${ }^{1}$ International Convention for the Protection of Performers, Producers of Phonograms and Broadcasting Organizations. Done at Rome on October 26, 1961 Available at: http:// www.wipo.int/treaties/en/text.jsp?file_id=289757 (accessed 01.07.2017).

${ }^{2}$ Convention for the Protection of Producers of Phonograms Against Unauthorized Duplication of Their Phonograms of October 29, 1971. Available at: http://www.wipo.int/treaties/ en/text.jsp?file_id=288582(accessed 01.07.2017).
} 
expand the list of protected objects, in comparison with the Rome Convention. The Geneva Convention provides its participants with more freedom in choosing measures to implement its provisions. Article 3 of the Convention includes the following measures: copyright law or other specific law; protection through legislation connected with unfair competition; criminal law protection.

By the end of the 20th century, the approach to an isolated international regulation in the area of copyright and neighboring rights had changed somewhat. The great importance of intellectual property rights in the world economy and intense struggle with international counterfeiting resulted in the situation when copyright and neighboring rights were frequently mentioned together in the discussions. And here the World Trade Organization (WTO) and World Intellectual Property Organization (WIPO) played their roles. For example, Section 1, Part II of TRIPS Agreement ${ }^{1}$ is called "Copyright and Related Rights". Article 14 is devoted to related rights, three traditional groups of these rights are enumerated here, just like in the Rome Convention.

In 1996 Geneva Diplomatic Conference concerning some issues of copyright and neighboring rights approved the so-called Internet-agreements, one being connected with copyright ${ }^{2}$, and the other - with performances and phonograms ${ }^{3}$. WIPO Agreement on performances and phonograms of December 20, 1996 is surely an outstanding document from the perspective of neighboring rights protection. This agreement refers to the protection of two out of the three traditional objects of neighboring rights, as it can be seen from its name. At the same time, this agreement does not cover audiovisual performances. The question of whether to provide protection to performances in audiovisual records within the Agreement on performances and phonograms was a key challenge for the participants of the Geneva Conference. A draft of the

\footnotetext{
${ }^{1}$ Agreement on Trade-related Aspects of Intellectual Property Rights (The TRIPS Agreement) of 15 April 1994. Available at: https://www.wto.org/english/docs_e/legal_e/27-trips_01_e.htm (accessed 01.07.2017).

${ }^{2}$ WIPO Copyright Treaty of December 20, 1996. Available at: http://www.wipo.int/treaties/en/text.jsp?file_id=295166 (accessed 01.07.2017).

${ }^{3}$ WIPO Performances and Phonograms Treaty of December 20, 1996. Available at: http://www.wipo.int/treaties/en/text. jsp?file_id=295578 (accessed 01.07.2017).
}

Agreement presented by the European Union contained some provisions on the protection of audiovisual performances while the United States insisted on the protection of performances in audio records only. Subsequently, the question of the international legal protection of audiovisual performances was only solved in 2012 with the approval of the Beijing Treaty on Audiovisual Performanc$\mathrm{es}^{4}$, which had not come into effect by the time of writing the present paper.

1996 Geneva Conference discussed a project for the third treaty - Treaty on Intellectual Property for Databases. The Conference participants did not manage to find common grounds about this document, and it was not adopted. The Treaty was supposed to protect non-original databases, in other words, ones which are not protected by copyright law. The same year EU adopted the Database Directive $^{5}$ with non-original databases being viewed by the law as sui generis. Thus, the European Union decided not to directly refer exclusive rights to nonoriginal databases to neighboring rights. The text of the draft WIPO Treaty on Intellectual Property for Databases does not consider the given right to be sui generis or neighboring right. However, the covering comments to the draft document state several times that this right is sui generis [3].

In conclusion of the analysis for the circle of neighboring rights in international law, it should be noted that presently WIPO is developing a project for Protection for Broadcasts and Broadcasting Organizations Treaty. WIPO started its work over the Treaty in 1997, but the participants of the discussion have not been able to find any consensus so far. For example, the Internet-broadcasting status, as well as the wordings defining the object under protection became the apple of discord.

\section{The Circle of Neighboring Rights in Foreign Law}

Legal protection of neighboring rights in foreign countries varies a lot. An in-depth discussion of this issue is beyond the scope of the present paper, therefore only key national approaches to

\footnotetext{
${ }^{4}$ Beijing Treaty on Audiovisual Performances of June 26, 2012. Available at: http://www.wipo.int/meetings/en/doc details.jsp?doc id=208966 (accessed 01.07.2017).

${ }^{5}$ Directive No. 96/9/EC of the European Parliament and of the Council, of 11 March 1996 on the Legal Protection of Databases. Available at: http://www.wipo.int/wipolex/ru/text.jsp? file_id=126789 (accessed 01.07.2017).
} 
regulate neighboring rights are described here. There are four such approaches or traditions.

1. The first group of national legal systems includes those countries which do not protect the rights of performers, producers of phonograms and broadcasting organizations. Iran is a good illustration of that, its Copyright $\mathrm{Law}^{1}$ and other legal documents do not even contain any provisions to protect the interests of the above mentioned beneficiaries. In case of Iran, this situation is a result of a purposeful policy, while in some other countries a lack of the intellectual property protection can be explained with military political factors. Take, for example, Somali which is in fact a dissociated state. In 1977 Copyright $\mathrm{Law}^{2}$ was adopted here, with no neighboring rights being recognized. Next forty years this Law has been neither revised, nor effective [11].

2. The second group of national legal systems is characterized by the fact that here neighboring rights are not recognized as they are, while the interests of performers, producers of phonograms and broadcasting organizations are protected by copyright law and legal institutes which are external towards it. This approach can be seen in the USA. The United States do not participate in the Rome Convention, however, they must follow its provisions due to their participation in TRIPS Agreement. Protection of neighboring rights in the USA can be called eclectic due to different means used for protection. Audio records are considered to be objects of copyright by Copyright $\mathrm{Law}^{3}$ (§ 102). Performers' rights also go under Copyright Law (§ 1101), however, this protection is not complete in comparison with the Rome Convention and European regulatory documents. Along with that, in the USA interests of performers are protected by the means which are external to intellectual property law, such as tort law, institute of unjust enrichment, protection against unfair competition and

\footnotetext{
${ }^{1}$ Act for Protection of Authors, Composers and Artists Rights of the Iran of January 12, 1970. Available at: http://www. wipo.int/wipolex/en/details.jsp?id=7708 (accessed 01.07.2017).

${ }^{2}$ Law on Copyright of the Somalia of September 7, 1977. Available at: http://www.somalilandlaw.com/SDR_Copyright_Law_1977_Som_.pdf(accessed 01.07.2017).

${ }^{3}$ Copyright Law of the United States of America of October 19, 1976. Available at: https://www.copyright.gov/title17/ (accessed 01.07.2017).
}

defamation. Besides, the so called right of publicity plays a specific role in protecting performers' interests $[10$, p. 576]. The right of publicity is a specific American doctrine with no similar analogues in continental law systems [4]. In simple terms, it can be explained by the right of a person to control a commercial exploitation of his/her own image.

The rights of broadcasting organizations are protected with different mechanisms in the United States. This protection system is complex and open. Copyright law and legislation on communication are the grounds for this system. P. Goldstein writes that the rights of broadcasting organizations in the USA are protected by Copyright Law [7, p. 202]. However, this protection is rather unusual in a sense that the law does not consider broadcast programs to be the objects of copyright law. Still, rights of broadcasting organization are interpreted in the context of doctrines and norms on protected works. Let us not forget that works must be original to go under the copyright law protection. Hence, not all TV and radio programs in the USA are protected by copyright law. J. A. L. Sterling refers to the protection of broadcasting organization interests as sui generis right established by the communication law and further adds that this protection can be provided by copyright law [12, p. 71]. For example, Article 325 of Communication Act of 19 June, 1934, forbids broadcasting organizations to retransmit signals of other organizations in an unauthorized manner ${ }^{4}$. Overall, according to the 1998 WIPO overview, in the USA the protection of the rights of broadcasting organization can be equally compared with the provisions of the 1961 Rome Convention [6].

3. The third group of legal systems mainly includes countries with Anglo-American law, where some objects can go under copyright law, just like in the USA, while others are covered by rights which are recognized within copyright law, but at the same time are separated from copyrights. Along with that, the phrase "neighboring rights" is not typically used in these laws. In case of Great Britain, 1988 Copyright, Design and

\footnotetext{
${ }^{4}$ Communication Act of the United States of America of June 19, 1934. Available at: http://www.wipo.int/wipolex/en/details.jsp?id=14821 (accessed 01.07.2017).
} 
Patent $\mathrm{Act}^{1}$ states the following items to be considered the objects of copyrights: 1) original works; 2) audio records and films; 3 ) printed layout of published works (Article1). The same Chapter of the Act considers general provisions on copyright, with a separate Article enumerating signals of broadcasting organizations (Article 6). The rights to these objects are called copyright in the Act. On the contrary, the rights to performances are regulated by the second part of the Act and have an independent status. Legislation systems of New Zealand ${ }^{2}$ and Australia $^{3}$ are characterized by the same approach. In case of India, the Copyright $\mathrm{Law}^{4}$ refers to audio records as the objects of copyright law (Article 13), just like it is in the laws in the above mentioned countries. However, rights separated from copyrights also include rights of broadcasting organization, besides performers' rights (Article 37 and 38).

The Canadian Copyright $\mathrm{Law}^{5}$ applies a very interesting approach, when all classical neighboring rights are separated from copyrights in terms of institutes, however, following Anglo-American traditions, they are still called "copyrights". In fact, the titles of the sections in this Law speak for themselves. The first section is called "Copyright and Moral Rights in Works", and the second part has a title "Copyright in Performers' Performances, Sound Recordings and Communication Signals and Moral Rights in Performers' Performances". The Canadian approach shows that today it is very difficult to draw a clear distinction between AngloAmerican and Civil law traditions in the protection of neighboring rights.

4. Finally, the fourth group of legal systems consists of the states with the Civil law system and

\footnotetext{
${ }^{1}$ Copyright, Designs and Patents Act of the United Kingdom of November 15, 1988. Available at: http://www.wipo.int/ wipolex/en/details.jsp?id=13284 (accessed 01.07.2017).

${ }^{2}$ Copyright Act of the New Zealand of December 15, 1994. Available at: http://www.wipo.int/wipolex/en/details.jsp?id= 14858 (accessed 01.07.2017).

${ }^{3}$ Copyright Act of the Australia of June 27, 1968. Available at: http://www.wipo.int/wipolex/en/details.jsp?id=15724 (accessed 01.07.2017).

${ }^{4}$ Copyright Act of the India of June 4, 1957. Available at: http://www.wipo.int/wipolex/en/details.jsp?id=2396 (accessed 01.07.2017).

${ }^{5}$ Copyright Act of the Canada (R. S. C., 1985, c. C-42). Available at: http://laws-lois.justice.gc.ca/eng/acts/c-42/ (accessed 01.07.2017).
}

the majority of the states with mixed law systems. Here all the so called classical neighboring rights are separated from copyrights in terms of institutes. German Copyright and Related Rights Law ${ }^{6}$ uses a term "verwandte Schutzrechte" (neighboring rights), French Code of Intellectual Property ${ }^{7}$ calls it "les droits voisins du droit d'auteur" (rights neighboring copyright), Italian Copyright and Neighboring Right Protection Law refers to it as "diritti connessi all'esercizio del diritto d'autore" (rights related to implementing copyrights). Sometimes instead of the term "neighboring rights" an expression "other rights" is legally used, for example, in Spanish Intellectual Property Law ${ }^{8}$ - "de los otros derechos de propiedad intellectual" (other rights of intellectual property), in Danish Copyright Law" - "andre rettigheder" (other rights).

The fourth group can be divided into three subgroups in terms of the number of objects being covered by neighboring rights. The first subgroup includes states with laws which recognize the rights under the Rome Convention only as neighboring rights. These laws are adopted, for instance, in Azerbaijan, ${ }^{10}$ the Republic of Belarus, ${ }^{11}$ Kazakhstan, ${ }^{12}$ Uzbekistan, ${ }^{13}$ Japan $^{14}$.

\footnotetext{
${ }^{6}$ Law on Copyright and Related Rights of the Germany of September 9, 1965. Available at: http://www.wipo.int/wipolex/en/details.jsp?id=16047 (accessed 01.07.2017).

${ }^{7}$ Intellectual Property Code of the France of July 1, 1992. Available at: http://www.wipo.int/wipolex/en/details.jsp?id= 14082 (accessed 01.07.2017).

${ }^{8}$ Consolidated Text of the Law on Intellectual Property of the Spain, regularizing, clarifying and harmonizing the Applicable Statutory Provisions (approved by Royal Legislative Decree No. 1/1996 of April 12, 1996). Available at: http://www. wipo.int/wipolex/en/details.jsp?id=17102 (accessed 01.07.2017).

${ }^{9}$ The Consolidated Act on Copyright of the Denmark of October 23, 2014. Available at: http://www.wipo.int/wipolex/en/ details.jsp?id=1146 (accessed 01.07.2017).

${ }^{10}$ Law on Copyright and Related Rights of the Republic of the Azerbaijan of June 5, 1996. Available at: http://www.wipo. int/wipolex/en/details.jsp?id=9165 (accessed 01.07.2017).

${ }^{11}$ Law on Copyright and Related Rights of the Republic of Belarus of May 17, 2011. Available at: http://www.wipo.int/ wipolex/en/details.jsp?id=10100 (accessed 01.07.2017).

${ }^{12}$ Law on Copyright and Related Rights of the Republic of Kazakhstan of June 10, 1996. Available at: http://www. wipo.int/wipolex/en/details.jsp?id=7974 (accessed 01.07.2017).

${ }^{13}$ Law on Copyright and Related Rights of the Republic of Uzbekistan of July 20, 2006. Available at: http://www.wipo. int/wipolex/en/details.jsp?id=9364 (accessed 01.07.2017).

${ }^{14}$ Copyright Act of the Japan of May 6, 1970. Available at: http://www.wipo.int/wipolex/en/details.jsp?id=8881 (accessed 01.07.2017).
} 
The second subgroup consists of the states with the rights proclaimed in the European Union's directives together with the classical triad of neighboring rights ${ }^{1}$. These are the following rights: the film producer's right, right to works which are published for the first time after they were transferred to public domain (non-published works), right to non-original photos, right to critical and scientific published works which are in public domain. EU member-states are not the only ones being influenced by the European Union policy in the area of copyright and neighboring rights. For example, being the most closed state of present times, North Korea at least declares protection of the rights of performers, producers of phonograms and videograms, broadcasting organizations ${ }^{2}$. The same list of neighboring rights is enshrined in, for instance, the legislations of Georgia, ${ }^{3}$ Latvia, ${ }^{4}$ Lithuania, ${ }^{5}$ Moldova, ${ }^{6}$ Turkmenistan, ${ }^{7}$ Ukraine, ${ }^{8}$ France ${ }^{9}$. In case of Estonia, the rights to non-published works and critical and scientific publications are considered to be neighboring rights as well, additionally to the four types of rights ${ }^{10}$. Along with

\footnotetext{
${ }^{1}$ Directive 2006/115/EC of the European Parliament and of the Council of 12 December 2006 on Rental Right and Lending Right and on Certain Rights Related to Copyright in the Field of Intellectual Property (codified version). Available at: http://www.wipo.int/wipolex/ru/text.jsp?file id=179834 (accessed 01.07.2017); directive No. 2006/116/EC of the European Parliament and of the Council of 12 December 2006 on the Term of Protection of Copyright and Certain Related Rights (codified version). Available at: http://www.wipo.int/wipolex/ ru/details.jsp?id=17095 (accessed 01.07.2017).

${ }^{2}$ Copyright Law of the Democratic People's Republic of Korea of March 21, 2001. Available at: http://www.wipo.int/wipolex/ en/details.jsp?id=9722 (accessed 01.07.2017).

${ }^{3}$ Law on Copyright and Neighboring Rights of the Georgia of June 22, 1999. Available at: http://www.wipo.int/wipolex/en/ details.jsp?id=1762 (accessed 01.07.2017).

${ }^{4}$ Copyright Law of the Latvia of April 6, 2000. Available at: http://www.wipo.int/wipolex/en/details.jsp?id=7658 (accessed 01.07.2017).

${ }^{5}$ Law on Copyright and Related Rights of the Lithuania of May 18, 1999. Available at: http://www.wipo.int/wipolex/en/ details.jsp?id=2852 (accessed 01.07.2017).

${ }^{6}$ Law on Copyright and Neighboring Rights of the Republic of Moldova of July 2, 2010. Available at: http://www.wipo.int/ wipolex/en/details.jsp?id=9795 (accessed 01.07.2017).

${ }^{7}$ Law on Copyright and Related Rights of the Turkmenistan of January 10, 2012. Available at: http://www.wipo.int/wipolex/ en/details.jsp?id=11443 (accessed 01.07.2017).

${ }^{8}$ Law on Copyright and Related Rights of the Ukraine of December 23, 1993. Available at: http://www.wipo.int/wipolex/ en/details.jsp?id=5115 (accessed 01.07.2017).

${ }^{9}$ Intellectual Property Code of the France of July 1, 1992

${ }^{10}$ Copyright Act of the Estonia of November 11, 1992. Available at: http://www.wipo.int/wipolex/en/details.jsp?id=1233 (accessed 01.07.2017).
}

that, these two rights are looked upon as other rights, not neighboring ones, for example, in Moldova Law. As for non-original photos and databases, they are considered to be objects of neighboring rights, for example in the legislation of Sweden ${ }^{11}$.

The third subgroup of the states with the Civil law systems includes the countries with a circle of neighboring rights being outside the European Union standards. Here we can think of, for example, Austria, Germany, Denmark, Italy. In Denmark, the rights to performance, phonograms, videograms, communication signals, photo images, catalogs and non-original databases, press-releases are considered to be other rights (Articles 65-72). What is more, the Chapter of the Law called "Different provisions" provides for the protection for the names of literary and fiction works, signatures and names of an artist (Articles 73, 74). In Germany, neighboring rights cover the following objects: 1) critical and scientific publications; 2) non-published works; 3) photos; 4) performances; 5) phonograms; 6) communication signals; 7) non-original databases; 8) printed layout of published works ( $\$ 70-87 \mathrm{~h}$ ). Along with that, movie producers' rights are regulated by another part of the Law devoted to special provisions concerning movies. In Austria, neighboring rights are considered to be the rights to 1) performances; 2) photos; 3) video records; 4) phonograms; 5) communication signals; 6) nonpublished works; 7) non-original databases; 8) letters and diaries; 9) portraits; 10) press-releases; 11) names of works (§ 66-80).

German and Austrian laws are similar to each other in terms of the key concepts, although they carry particular legal traditions. And these traditions are likely to be more important, if possible, than some European Union directives. For example, unlike the German Law, the Austrian Law does not recognize the right to critical and scientific published works which are in the public domain. M. Walter sees the explanation in the fact that the provisions of Article 5 of the EU Directive

\footnotetext{
${ }^{11}$ Act on Copyright in Literary and Artistic Works of the Sweden of December 30, 1960. Available at: http://www.wipo.int/ wipolex/en/details.jsp?id=13057 (accessed 01.07.2017).
} 
on the terms of the copyright and particular neighboring rights protection are not obligatory [13, p. 120].

\section{The Circle of Neighboring Rights in Russian Law de lege lata}

Legislative recognition of neighboring rights in Russia has gone through three stages. The first stage is connected with the Fundamental Principles of the Civil Legislation of the Union of the SSR and the Republics of 31 May, 1991, applied over the territory of the Post-Soviet Russia ${ }^{1}$. In this case we refer to the period from 3 August, 1992, till 3 August, 1993. Article 141 of the Fundamental Principles established protection for the rights of performers, producers of audio and video records, broadcasting organizations. The second stage, which took place in the period when the RF Law "On Copyright and Neighboring Rights" of 9 July, $1993^{2}$ was in effect, was characterized by the protection of rights of performers, phonogram producers, broadcasting or cable organizations, those being referred to as neighboring rights. Finally, the third stage started on 1 January, 2008, when the fourth part of the RF Civil Code came into force ${ }^{3}$. Chapter 71 of the Code recognizes neighboring rights to be the rights of 1) performers; 2) phonogram producers; 3 ) broadcasting or cable organizations; 4) database makers; 5) publishers.

Just like many other countries, Russia recognized protection of neighboring rights under the impact of the international and European laws rather than due to its own national traditions of intellectual property law. In terms of these traditions, we should point out the unique background of the Soviet copyright law development. For example, 1964 RSFSR Civil Code ${ }^{4}$ protected radio and TV programs as objects of the copyright law (Article 486). Subsequently, Russia recognized classical neighboring rights at the end of 20 century as our state was thinking of adhering to the 1961 Rome Convention. The Russian Federation acceded this

\footnotetext{
${ }^{1}$ Fundamental Principles of the Civil Legislation of the USSR and the Republics of 31 May, 1991. Available at: http://pravo. gov.ru/proxy/ips/?docbody=\&nd $=102011632 \&$ rdk=\&backlink $=1$ (accessed 01.07.2017).

${ }^{2}$ Law on Copyright and Neighboring Rights of the Russian Federation of July 9, 1993. Available at: https://en.wikisource.org/wiki/Russian_Federation._Law_on_Copyright_and Neighboring_Rights (accessed 01.07.2017).

${ }^{3}$ Part four of Civil Code of the Russian Federation of December 18, 2006. Available at: http://www.wipo.int/wipolex/en/ details.jsp?id=12785 (accessed 01.07.2017).

${ }^{4}$ Civil Code of the RSFSR of June 11, 1964. Available at: http://kremlin.ru/acts/bank/3 (accessed 01.07.2017).
}

Agreement on 26 May, 2003. No other rights, recognized to be neighboring rights in these or those legal systems, must be protected in Russia. However, Part Four of the RF Civil Code was grounded on the experience of the European Union, and as a result the classical triad of neighboring rights was supplemented with the rights of makers of nonoriginal databases and rights of publishers (persons who lawfully made public a work owned by the public). The developers of the draft version of Part Four of the Civil Code justified this expansion of the range of neighboring rights with the Directives of the European Union ${ }^{5}$. Along with that, the rights of film (video record) producers, rights to non-original photos, rights to critical and scientific publications of works owned by the public - the rights recognized in the EU Directives were not on agenda when preparing Part Four of the RF Civil Code.

\section{The Circle of Neighboring Rights in Russian Law de lege ferenda}

The question of what circle of neighboring rights is the most desirable and appropriate for the modern Russian legislation system has two possible interpretations. First of all, despite the clear list of neighboring rights specified in Chapter 71 of the RF Civil Code, the Russian legislation recognizes a number of other rights which are somehow connected with copyright and whose nature is not quite clear from the provisions of the corresponding laws. Further, this paper attempts to determine whether the status of these rights should be changed at the legislative level and be regarded as neighboring rights. Secondly, considering Austrian or German experience of the neighboring right protection, it is reasonable to ask a question whether it is justified to recognize these rights, which are new for the Russian legislation. To find an answer to this question means to carry out a comprehensive research which is outside the scope of the present paper. The point is that the range of neighboring rights which are potentially new for the Russian legislative system is quite wide, and recognition of each of these rights should be justified separately. As it was already mentioned, establishment of neighboring rights limits public interests in free exploitation of the corresponding objects. Therefore, any expansion of these rights is rather sensible for the society.

\footnotetext{
${ }^{5}$ Explanatory Note to the Draft of Part Four of Civil Code of the Russian Federation. Available at: http://www.consultant.ru/ cons/cgi/online.cgi?req $=$ doc\&base $=$ PRJ $\& n=42759 \&$ dst $=10000$ 1\#0 (accessed 01.07.2017).
} 
1. The first right which we would like to look at is the right of publishers of encyclopedias, encyclopedic dictionaries, periodic and serial collections of scientific works, newspapers, journals and other periodic works to use these publications (Clause 7, Article 1260 of the Civil Code). What is more, a publisher is entitled with the rights to state his name or to have it stated with any exploitation of these publications. The provisions on the right of publishers to exploit the publications were transferred from Article 13 of the RF Law "On Copyright and Neighboring Rights" to the Civil Code. At the same time, no particular information regarding the content, validity period and other parameters for the right in question were specified. It is a mistake to look at publishers' right to exploit publications as an exclusive copyright within the Civil law systems since the objects of copyrights can only be the original works. In contrast, publications themselves are the objects of publishers' right with no regard to any condition.

We believe it would be fair to include publishers' right to the publication exploitation into the circle of the neighboring rights. Along with that, there is a need to specify the content, validity period for this right, as well as the procedure to exercise this right. Provisions concerning the publishers' right articulated in $\S 6$, Chapter 71 of the RF Civil Code can become the grounds for new provisions on the right to periodic works.

2. The right of the maker to the audiovisual work (video record or videogram) is the next potential point in the Russian circle of neighboring rights. This right was already referred to as a neighboring right in the 1991 Fundamental Principles of Civil Legislation, and its later exclusion from the circle of neighboring rights is, to some extent, a paradox. The point is that some provisions of the Russian law can be interpreted in a way that the right of a maker (producer) to the audiovisual work is still recognized and exists together with an exclusive copyright to this work. Article 1273 of the RF Civil Code states that when phonograms and audiovisual works are reproduced only for personal purposes, the authors, performers, producers of phonograms and audiovisual works have the right to remuneration as it is stated in Article 1245 of the Code. Clause 3, Article 1245 of the RF Civil Code states that this remuneration is divided among the rightholders as follows: forty per cent goes to the authors, the performers and producers of phonograms or audiovisual works receive thirty per cent each. This remuneration is compensatory by nature (Clause 1, Article 1245 of the RF Civil Code). Its purpose is to cover the financial losses occurred with the rightholders due to the impossibility to receive a remuneration in each case when phonograms and audiovisual works are reproduced for personal purposes.

Thus, a producer is a holder of the right to remuneration independent in relation to the authors of the film. At the same time, Articles 1263 and 1240 of the Civil Code declare that the producer is considered to be a derivative holder of exclusive copyrights to the audiovisual work. If a producer purchases an exclusive right to a movie from the authors of the movie, as it happens in most cases, then his share in a reward (Article 1245 of the RF Civil Code) increases to seventy per cent.

This controversy between the producer's status as an independent holder of the right to remuneration for the exploitation of an audiovisual work for personal purposes and as a derivative holder of an exclusive copyright to this object should be eliminated with the legal recognition of the neighboring rights for a producer of an audiovisual work. Provisions concerning the right to phonograms articulated in $\S 3$, Chapter 71 of the RF Civil Code can become the grounds for new provisions on this right.

3. Finally, museums' right to publish museum items and collections (hereinafter referred to as museum items) is the most ambiguous right among other ones, which are, so to say, in the shadow of copyright law. Article 36 of the Federal Law "On Museum Collection of the Russian Federation and on Museums in the Russian Federation" ${ }^{1}$ states that the museum which has museum items holds the right to the first publication of these. Museums can transfer the right to exploit reproductions of their items for commercial purposes in accordance with the procedure established by the owner of the museum items. Besides, arts, souvenirs, printed and other published products and consumer goods can be produced with the images of the museum items, which should be permitted by the museum's authorities.

\footnotetext{
${ }^{1}$ Federal Law on Museum Collection of the Russian Federation and on Museums in the Russian Federation of May 26, 1996. Available at: http://docs.cntd.ru/document/9020113 (accessed 01.07.2017).
} 
Thus, museums are, to some extent, monopolies in the area of exploitation of the images of museum items. And this monopoly is not connected with the duration of the term for copyright protection of a museum item. Both in Russia and abroad museums being plaintiffs at courts put all their efforts to prevent the images of the museum items to be freely used, which causes quite a negative response from the public. G. Petri is right in saying that public museums try to spread knowledge and to make their collections accessible, however, in case of the images of these collections, they very often stick to restrictive policy [8].

The museums' right to the publication of museum items rarely becomes the subject of scientific studies. E. P. Gavrilov gives his interpretation of the Article 36 of the Law on Museums and states that there is no exclusive right of museums to reproduction of museum items, however, museums have the right to provide a service on a fee basis: to provide an interested person with an access to a museum object to produce its image [1, pp. 360361]. The scholar considers the so called museum right to be a type of property rights [1, p. 362]. He believes that the Law on Museums protects museum items as material objects, as objects of property rights. "The right to production of other material objects (things) reproducing (copying) museum items itself does not belong and cannot belong to property rights to museum objects", writes professor E. P. Gavrilov [1, p. 356].

Undoubtedly, the right to reproduce museum items cannot belong to the circle of property rights. However, the interpretation of Article 36 of the Law on Museums according to which this article establishes property rights appears to be wrong. Paragraph 2, Article 36 of the Law clearly states the right to exploit reproduction of museum items for commercial purposes. Paragraph 3, in its turn, specifies the exploitation of images of museum items in souvenirs and other replicated goods. Thus, an image of a museum item and the object itself are different objects with different recognized rights. An image of a museum item is a non-material object, while the right to exploit it is a property absolute right, hence this right is an exclusive right by its nature. In terms of functions, a museum's exclusive right to publish museum items is close to a publisher's right. Provided that museums' right must stay within the Russian law system, this right should be regarded as a neighboring right. However, we doubt whether it is necessary and fair to have this right as it is.

\section{Conclusion}

Undoubtedly, neighboring rights are presently the most dynamically developing institute in intellectual property law as the number of objects covered by these rights is constantly increasing.

Austrian Law on Copyright in Works of Literature and Art and on Related Rights of 9 April, 1936 was the first to recognize neighboring rights. The term "verwandte Schutzrechte" (neighboring rights) was used both in the title and in the wording of the Law since its approval.

Neighboring rights had been protected on the international level earlier than they were recognized in the majority of countries. Conventions in this area of intellectual property are known for their provisions to be pioneering, innovative for national legislations. At the same time, the range of neighboring rights in the international law has not changed from the 1961 Rome Convention. It includes the so called classical neighboring rights: rights of performers, phonogram producers and broadcasting organizations.

Despite the international standards in the protection of neighboring rights, they are regulated differently in different countries.

The first group of national legal systems includes those countries which do not protect rights of performers, producers of phonograms and broadcasting organizations. The second group is characterized by the fact that here neighboring rights, as they are, are not recognized, while the interests of performers, producers of phonograms and broadcasting organizations are protected by copyright law and legal institutes which are external towards it. This approach is clearly illustrated by the USA. The third group of legal systems mainly includes countries with the Anglo-American law, where some objects can go under copyright law, just like in the USA, while other objects are covered by the rights which are recognized within copyright law. Along with that, these rights are 
separated from the copyrights, but they are unlikely to be called neighboring rights. The fourth group includes states with the Civil law system and the majority of the states with mixed law systems. Here all the so called classical neighboring rights are separated from copyrights in terms of institutes.

Just like many other countries, Russia recognized the protection of neighboring rights under the impact of the international and European laws rather than due to its own national traditions of intellectual property law. Here classical neighboring rights were recognized to adhere to the 1961 Rome Convention. The draft version of Part Four of the RF Civil Code was partly grounded on the experience of the European Union, and as a result the classical triad of the neighboring rights was supplemented with the rights of makers of non-original databases and publishers' rights.

With its external logic and structuredness, the Russian legislation in the area of intellectual property recognizes also a number of other rights which are neighboring rights by their nature and which should be regulated in Chapter 71 of the RF Civil Code devoted to these rights. These are the following rights: 1) right of publishers of encyclopedias, encyclopedic dictionaries, periodic and serial collections of scientific works, newspapers, journals and other periodic issues to exploit these publications; 2) right of producers of audiovisual works; 3) museums' rights to publish museum items and museum collections. The museums' right should be regulated as one of neighboring rights provided it remains within the Russian law system. However, we doubt whether it is necessary and fair to have this right as it is.

\section{References}

1. Gavrilov E. P. Pravo intellektual'noy sobstvennosti. Avtorskoe pravo $i$ smezhnye prava. $X X I$ vek [Intellectual Property Right. Copyright and Neighboring Rights. $21^{\text {st }}$ Century]. Moscow, 2016. 880 p. (In Russ.).

2. Liptsik D. Avtorskoe pravo i smezhnye prava [Copyright and Neighboring Rights]. Moscow, 2002. 788 p. (In Russ.).

3. Basic Proposal for the Substantive Provisions of the Treaty on Intellectual Property in Respect of Databases to Be Considered by the Diplomatic Conference. Geneva, 1996. Available at: http://www.wipo.int/meetings/en/doc_details.jsp ?doc_id=2487 (accessed 01.07.2017). (In Eng.).
4. Bergmann S. Publicity Rights in the United States and Germany: A Comparative Analysis. Loy. L. A. Ent. L. Rev. 1999. No. 479. Available at: http://digitalcommons.lmu.edu/cgi/viewcontent.cgi?article $=1387 \&$ context $=$ elr $\quad$ (accessed 01.07.2017). (In Eng.).

5. Bodenhausen G. H. C. Protection of "Neighboring Rights". Law and Contemporary Problems. 1954. Spring. Pp. 156-171. Available at: http:// scholarship.law.duke.edu/cgi/viewcontent.cgi?ar ticle $=2592 \&$ context $=$ lcp (accessed 01.07.2017). (In Eng.).

6. Existing International, Regional and National Legislation Concerning the Protection of the Rights of Broadcasting. Geneva, 1998. Available at: http://www.wipo.int/edocs/mdocs/ copyright/en/sccr_1/sccr_1_3.html (accessed 01.07.2017). (In Eng.).

7. Goldstein P. International Copyright: Principles, Law, and Practice. New York, 2001. 618 p. (In Eng.).

8. Petri G. The Public Domain vs. the Museum: The Limits of Copyright and Reproductions of Two-dimensional Works of Art. Journal of Conservation and Museum Studies. 2014. No. 12(1): 8. Pp. 1-12. Available at: http://dx.doi.org/ 10.5334/jcms.1021217 (accessed 01.07.2017). (In Eng.).

9. Ricketson S., Ginsburg Jane C. International Copyright and Neighbouring rights: The Berne Convention and Beyond. $2^{\text {nd }}$ ed. New York, Oxford, 2006. 1652 p. (In Eng.).

10. Sanhita Ambastt. Protecting Performers' Rights: Does India Need Law Reform? Journal of Intellectual Property Rights. 2008. Vol. 13. November. Pp. 574-582. (In Eng.).

11. Somaliland Copyright Law. Available at: http:// www.somalilandlaw.com/somaliland_copyright law.html (accessed 01.07.2017). (In Eng.).

12. Sterling J. A. L. World Copyright Law. London, 2003. 1357 p. (In Eng.).

13. Walter $M$. Grundriss des Österreichischen Urheber-, Urhebervertrags- und Verwertungsgesellschaftenrechts. Wien, 2016. 219 p. (In Germ.).

\section{References in Russian}

1. Гаврилов Э. П. Право интеллектуальной собственности. Авторское право и смежные права. XXI век. М.: Юрсервитум, 2016. 880 с.

2. Липиик Д. Авторское право и смежные права. М.: Ладомир, 2002. 788 с.

3. Basic Proposal for the Substantive Provisions of the Treaty on Intellectual Property in Respect of Databases to Be Considered by the Diplomatic 
Conference. Geneva, 1996. URL: http://www. wipo.int/meetings/en/doc details.jsp?doc id $=24$ 87 (дата обращения: 01.07.2017).

4. Bergmann S. Publicity Rights in the United States and Germany: A Comparative Analysis // Loy. L. A. Ent. L. Rev. 1999. № 479. URL: http://digitalcommons.lmu.edu/cgi/viewcontent. cgi?article $=1387 \&$ context=elr (дата обращения: 01.07.2017).

5. Bodenhausen George H.C. Protection of "Neighboring Rights" // Law and Contemporary Problems. 1954. Spring. Pp. 156-171. URL: http://scholarship.law.duke.edu/cgi/viewcontent. cgi?article $=2592 \&$ context=lcp (дата обращения: 01.07.2017).

6. Existing International, Regional and National Legislation Concerning the Protection of the Rights of Broadcasting. Geneva, 1998. URL: http://www.wipo.int/edocs/mdocs/copyright/e n/sccr_1/sccr_1_3.html (дата обращения: 01.07.2017).

7. Goldstein P. International Copyright: Principles, Law, and Practice. New York, 2001. 618 p.
8. Petri G. The Public Domain vs. the Museum: The Limits of Copyright and Reproductions of Two-dimensional Works of Art // Journal of Conservation and Museum Studies. 2014. № 12(1): 8. Pp. 1-12. URL: http://dx.doi.org/ 10.5334/jcms.1021217 (дата обращения: 01.07.2017).

9. Ricketson S., Ginsburg Jane C. International copyright and neighbouring rights: The Berne Convention and Beyond. 2 ed. New York; Oxford, 2006. $1652 \mathrm{p}$.

10. Sanhita Ambastt. Protecting Performers' Rights: Does India Need Law Reform? // Journal of Intellectual Property Rights. 2008. Vol. 13. November. Pp. 574-582.

11. Somaliland Copyright Law. URL: http://www. somalilandlaw.com/somaliland_copyright_law. html (дата обращения: 01.07.2017).

12. Sterling J. A. L. World copyright law. London, 2003. $1357 \mathrm{p}$.

14. Walter M. Grundriss des Österreichischen Urheber-, Urhebervertrags- und Verwertungsgesellschaftenrechts. Wien, 2016. $219 \mathrm{~s}$. 